\title{
Membrane Microdomains Defining Cell Adhesion and Signaling
}

\author{
細胞接着と細胞シグナル機能を支配する細胞膜マイクロドメイン
}

\author{
Sen-itiroh Hakomori \\ Pacific Northwest Research Institute, University of Washington, 720 Broadway, Seattle, WA 98122, USA \\ FAX: 1-206-726-1222, E-mail hakomori@u.washington.edu
}

Key Words :glycosphingolipid clustering, detergent insolubility, cell adhesion, tetraspanin, signal transducer

\section{Abstract}

Following a retrospective view on development of the present concept of microdomain, current views of multiple microdomains are briefly presented. Based on physical properties of membrane components, some lipids are clustered, segregated from other lipids, and organized with cytoplasmic lipophilic signal transducer molecules and with transmembrane receptors with hydrophobic domain, and their associated partners. Typical examples are: (i) glycosphingolipids (GSLs) and sphingomyelin organized with cSrc, Src family kinases, and small G-proteins, collectively termed "glycosignaling domain (GSD)" and involved in GSL-dependent cell adhesion and signaling; (ii) caveolae and caveolar membrane, characterized by high content of cholesterol and caveolin, organized with GPI-anchors and signal transducers, and involved in endocytosis and signal transduction; (iii) integrins and tetraspan membrane proteins (TMP) complexed with some type of GSL; (iv) growth factor receptors with tyrosine kinases complexed with cholesterol-enriched domain, with or without some type of GSL. The defined composition and association of signal transducer molecules in microdomain iii and iv is yet unclear. Relative quantity and proportion of these types of microdomain differs and is characteristic for different types of cells.

\section{A. Retrospective on Membrane Microdomain: Is This Con-} cept a Revival of the "Mosaic" or "Plate" Model?

Certain lipid and protein components are organized to form membrane microdomains, the functional "plate" involved in adhesion and signaling at the cell surface membrane*. In view of varia-
要 約

最初にマイクロドメインの概念がつくられて来た過程を 回想し、ついで現在考えられている幾つかの組成と機能の異 なったマイクロドメインについて概説した。膜組成の物理的 性質(物性)の相違にもとづき或種のリピドは、ほかの膜リピ ドから分離して、クラスターをつくり、原形質シグナル伝達 分子や貫膜性レセプター、それに伴う膜成分と会合し、いく つかの異なるマイクロドメインをつくる。典型的な例として (i)GSLとスフィンゴミエリンがcSrc, Srcファミリーキナーゼ、 小型G-蛋白と会合して形成されるグリコシグナルドメイン (GSD)、(ii)高濃度のコレステロールとカベオリン、GPI-アン カーやシグナル伝達分子からなるカベオラメンブレン、(iii)イ ンテグリン-テトラスパニン複合体とGSLからなるマイクロド メイン、(iv)細胞成長因子レセプターがコレステロール含量の 高い膜と会合しているマイクロドメインなどがある。(iii)と (iv)の組成については不明の点が少なくない。これら異なった マイクロドメインの量や性質は細胞の性質により大きく異な ることが考えられる。

A. 回想; 細胞膜マクロドメイン:この概念は曾て提唱された “モザイク” 又は “プレート”モデルへの復帰か？

細胞表面膜で細胞接着やシグナル伝達にたづさわる膜機 能 “プレイト”、則ち細胞膜ミクロドメイン*は、特定の脂質 やタンパク質によって構成されている。細胞膜画分の化学組
*The term "raft", which is now often used, was introduced as being opposed to the term "caveolae". However, "raft" connotes a moving or floating platform, which is not appropriate when much of the domain is involved in cell adhesion, as is shown by increasing evidence. If a general term analogous or parallel to "raft" is needed, perhaps "plate" (Jain and White, 1977), "aggregate" (Tillack et al., 1983), or "patch" (Kojima and Hakomori, 1991a) could be used. Terms such as "DIM," "DRM," "caveolar membrane," etc. should be used for connotation of a mixture of membranes. However, if composition and function depend on GSL, the term "GSL enriched microdomain" (GEM) or "GSL-signaling domain" (GSD) is preferable, as discussed in the text.
*最近、しばしば使われる“ラフト(筏)”という言葉は、従来使われて いた“カべオラ”に対抗して提唱された言葉であるが、それは浮かん で動いているプラットホームを意味する。マイクロドメインの多くが 細胞接着に関与している証拠が増えてきたことから、現在では適切な 表現ではない。もしも、ラフトに対応した一般的な呼び方が必要な ら、“プレート” (Jain and White, 1977)や“凝集体” (Tillack et al., 1983) もしくは“パッチ” (Kojima and Hakomori, 1991b)などの表現が適切で あろう。DIMやDRM、カベオラメンブレンなどの従来の呼び名は膜の 混合物という意味では“ラフト”と同義語である。しかし、構成成分 や機能がGSLに依存しているならば、GSLマイクロドメイン(GEM)、 もしくはGSLシグナリングドメイン(GSD)という呼び方が好ましい。 
tion in chemical components and their organization in membrane fraction, it is assumed that multiple microdomains exist, and that their functions are different, as will be discussed in Section C. The concept of multiple microdomains in plasma membrane is generally viewed as having evolved from the concept of random or homogeneous distribution of membrane proteins in the "sea" of lipid bilayer as proposed in the "fluid mosaic" model of (Singer and Nicolson, 1972). I personally view the current concept of multiple microdomains, rather, as a revival of the "mosaic model" which predates the Singer \& Nicolson model.

People may have forgotten a long-term debate on the basic structure of biological membranes in general. Instead of citing many classic studies along this line, I will simply present the view of D.F.H. Wallach, published as a symposium record just one year before the Singer \& Nicolson paper. Based on a number of physical studies, including spectral data, electron micrographs, and cooperative behavior of soluble oligomeric proteins bound to lipids, Wallach summarized the idea that membranes consist of multiple mosaic units which contain membrane protein core bound to lipids (Wallach, 1971). Some of the data and ideas presented in this 1971 review are reproduced in Fig. 1A,B. The "plate model," a modification of the fluid mosaic model of biomembranes, was proposed by M.K. Jain and H.B. White (Jain and White, 1977), who emphasized that the "biomembrane continuum is broken up into a number of relative rigid plates or patches which are in relative motion with respect to each other." The ordered and rigid regions may be separated from each other
成と構成の多様性を考えると、第C章で述べるように機能の異な る様々なマイクロドメインの存在が予想される。マイクロドメ インの概念は1972年にSinger\&Nicolsonにより提唱された流動モ ザイクモデルから発展したものと一般に考えらてれる。即ち “リピド二重層の海の中にランダムに分布する膜タンパク質” というイメージに基づいている。しかし私個人はSinger\& Nicolsonのモデル以前に提唱されたモザイクモデルへの復帰、叉 はプレイトモデルとの酷似を指摘したい。

生体膜の基本構造に関する長い間の議論を忘れてしまって いる人々が多いかもしれない。これに関する多くの過去の研究 を引用する換わりに、Singer\&Nicolsonの論文が公表される1年 前にシンポジウムレコードとして発表されたD.F.H. Wallachの見 解を簡単に紹介したいと思う。スペクトルデータや電子顕微鏡 写真、脂質に結合した水溶性オリゴメリックタンパク質の動き の協同性など、数多くの物理学的な研究を基礎にWallachは、細 胞膜は脂質に結合した細胞膜タンパク質のコアを含んだ多様な モザイクユニットからなっているという考えを要約した (Wallach,1971)。このレビューで紹介された幾つかのデータや考 えを図1A,Bに示した。Singer\&Nicolsonモザイクモデルを部分的 に修正したプレートモデルは1977年にM.K.JainとH.B.Whiteに よって提唱され、生体膜の均一な連続性は性質の異なる膜領域 (プレイト)の存在により分断されている可能性が示唆された。即 ち、膜成分の配向性がはっきりして流動性が少ない堅い領域 と、配向性が乱雑で流動性の高い領域に分れ、夫々の領域(プレ イト)の相対的運動生が異なる可能性が指摘された。これら“プ
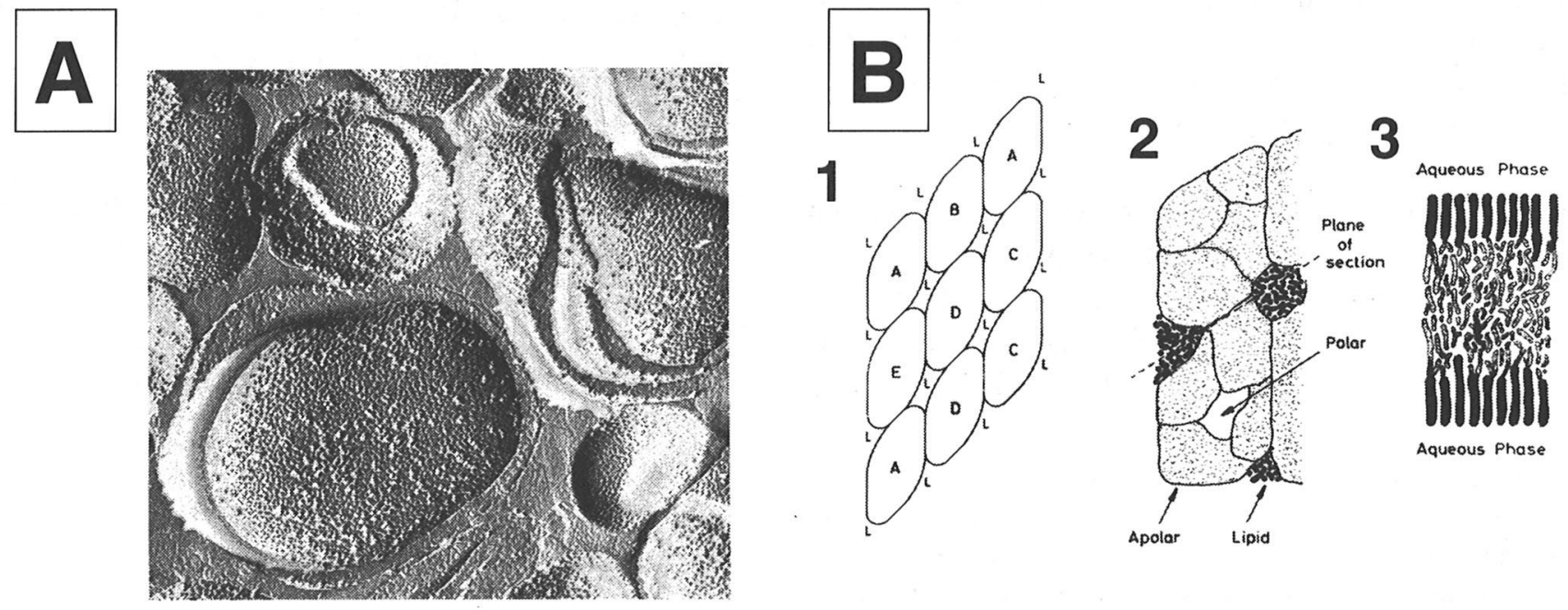

Fig. 1. Unit model or mosaic model of membrane. The concept that biological membranes are composed of multiple lipoprotein units (mosaic units) was supported partially or fully by a few membrane biochemists prior to proposal of the Singer \& Nicolson model. The images shown here are from (Wallach, 1971). Panel A, structure of erythrocyte membrane shown by EM with freeze-fracture etching. Lattice structure of membrane-associated particles is revealed at the fracture surface. This structure may correspond to clustered GSLs or SM in our current concept. Panel B1, conceptual drawing of membrane protein units (A, B, etc.) surrounding bound lipids (L). Panel B2, mosaic units of lipoprotein, consisting of diverse lipoprotein subunits and tangential polarities including polar hole and cluster of lipids. Panel B3, transverse polarity of membrane. Membrane units or mosaic units in these illustrations are similar to the microdomain concept. 
by fluid and disordered regions. Structural and functional units play a role in transport and cellular interaction, and show cooperativity among themselves in order to maintain overall function of biological membranes. This view, particularly the plate model, was remarkably similar to the current concept of microdomains, although the idea of signal transduction was premature and fragmentary at that time. The plate model, in comparison with our current concept of GSL patch(Kojima \&Hakomori, 1991) or GSL signaling domain (Hakomori et al., 1998), is shown in Fig. 2A, B, C, D.

\section{B. Development of Our Current Concept of Membrane}

\section{Microdomain}

The current concept of membrane microdomain developed slowly but steadily during the past two decades. Major observations leading to the current concept of multiple membrane microdomains are illustrated chronologically in Fig. 3, and each episode is explained in the following paragraphs, a through $\mathbf{h}$.

\section{A}
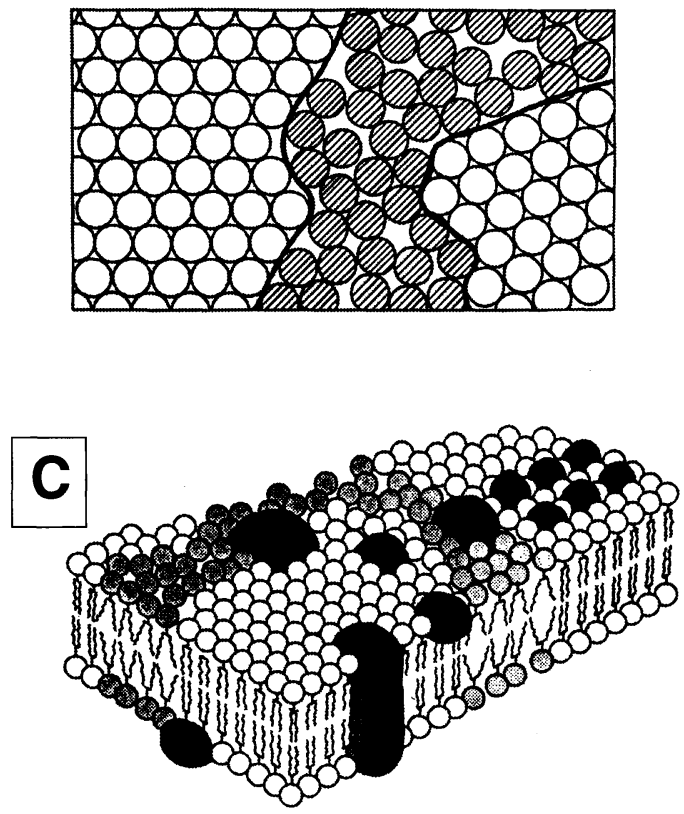

レイト”は膜の構造・機能的ユニットを形成し、膜の輸送や細 胞間相互作用に役割を演じ、細胞膜全体の機能を維持するため に、夫々のプレイトの間で協調性を示す。このプレイトモデル が提唱された頃は未だシグナル伝達の考えは未熟で断片的では あったため、プレイトの機能としてのシグナル伝達については 言及されていないが、プレイトモデルは現在のマイクロドメイ ンという概念に非常によく類似している。GSL patch(Kojima \& Hakomori, 1991)、もしくはGSLシグナルドメイン(Hakomori et al., 1998)という今の概念と比較したプレートモデルを図2A, B, C, D に示した。

B． 細胞膜マイクロドメインという概念の発展

細胞膜マイクロドメインという今の概念は 20 年間でゆっく りと、しかし着実に発展してきた。多様な細胞膜マイクロドメ インという今の概念に至った主な発見 (aからh) は、図3に年代順 に載せておいた。それぞれのエピソードについては次に説明す る。
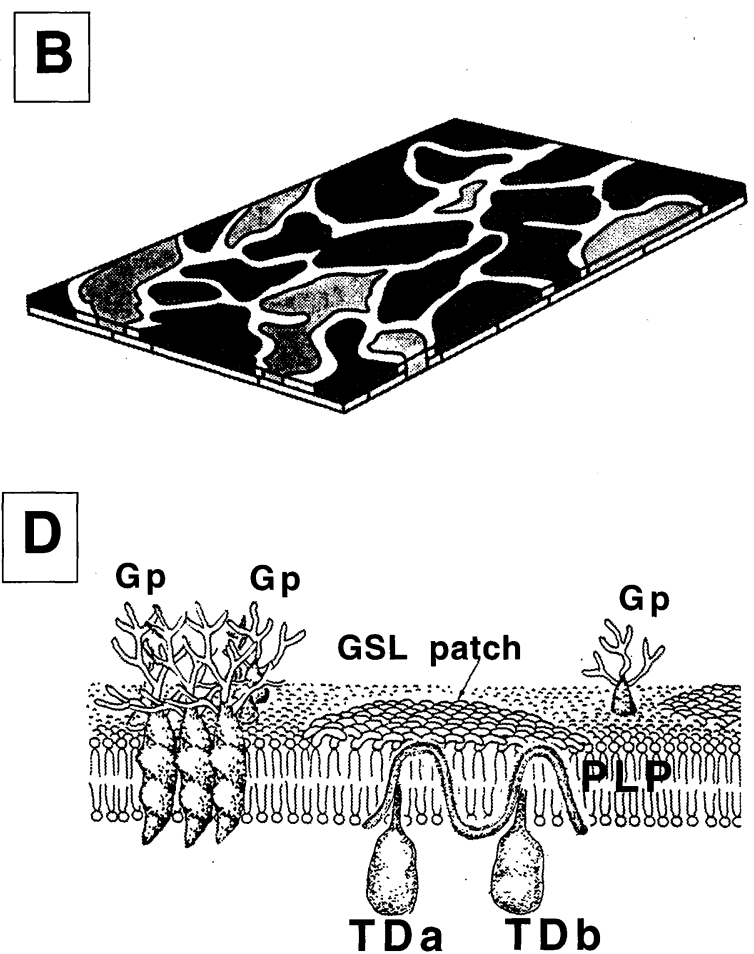

Fig. 2. Membrane "plate" model proposed by Jain \& White (panels A, B, C), in comparison to current concept of GSL microdomain or GSL signaling domain (from Kojima \& Hakomori, 1991; Hakomori et al., 1998). A, organized lipid molecules (white circles) are separated from domain consisting of disorganized lipids (shaded circles). B, the two regions as in A are viewed as distinct "plates" (shown as black and gray), each having characteristic properties specified by their components. C, coexistence of distinct "plates" incorporated in lipid bilayer. "Ordered" head groups (white circles) are associated with parallel, rigid lipids. "Disordered" head groups (gray circles) are associated with nonparallel, fluidic lipids composed of phospholipids which inherently contain unsaturated fatty acid. D, GSL microdomain (patches) separated from clustered glycoproteins (Gp). Transducer molecules (TDa, TDb) are associated with GSL microdomain and proteolipid proteins (PLP) which modulate signal transduction. Note the similarity between A-C and D in terms of distinct separation of membrane components due to physical properties. 


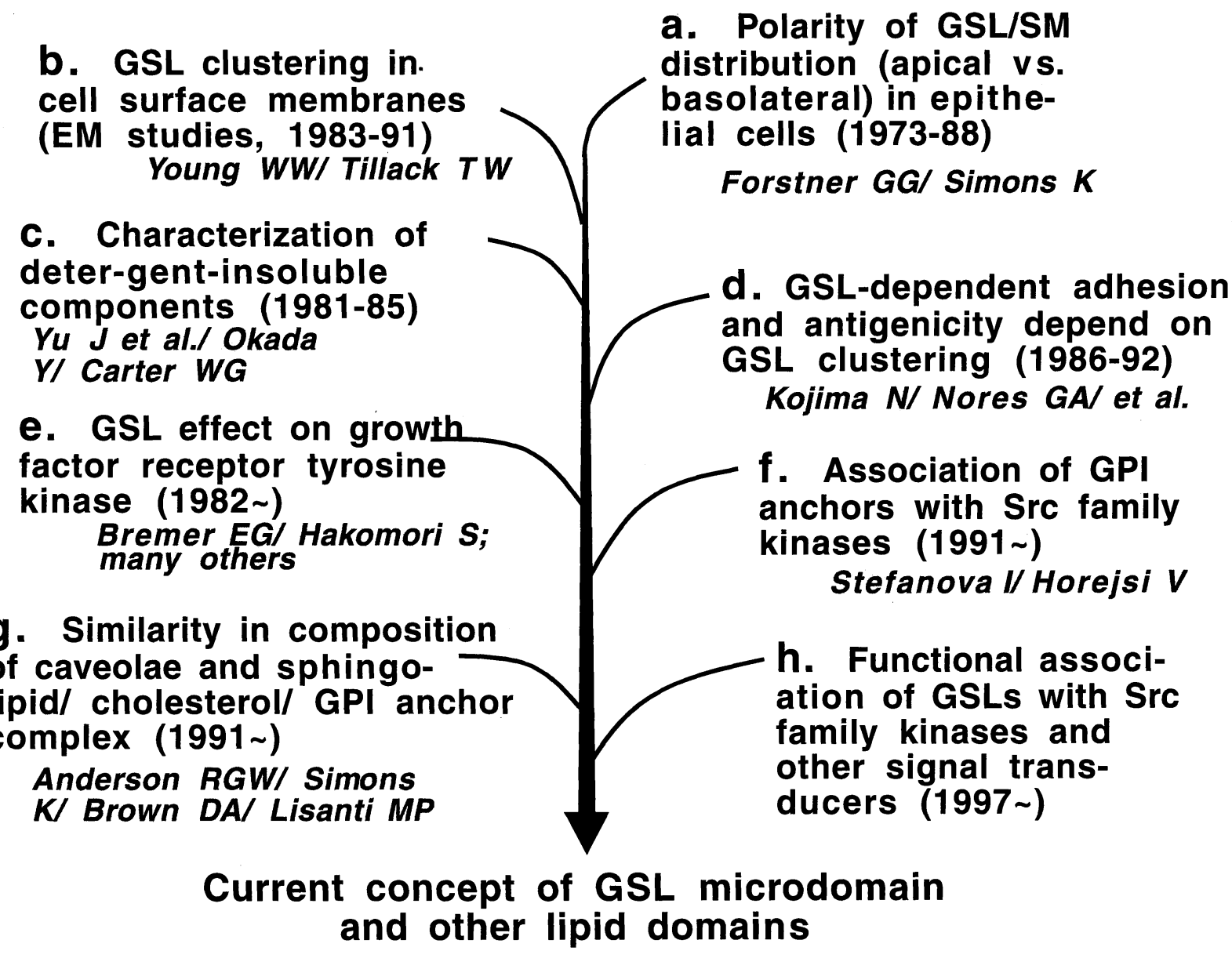

Fig. 3. Independent observations a to $\mathrm{g}$ (in chronological order) led to the concept of GSL microdomains, particularly functional association of GSL with signal transducers (h). Names of scientists principally involved in each observation are shown in italics with shadow background.

B-1. Initial Observation on Cellular polarity: Apical vs. Basolateral Membrane of Epithelial Cells

Two different properties of cell surface membranes are suggested by the observation that GSLs and SM are present in higher concentration in apical than in basolateral membrane in epithelial cells. This was demonstrated initially by enrichment of GSLs, particularly fucose-containing GSLs (a then-newlydiscovered type of GSL), in villus membrane as compared to brush border or whole tissue of rat intestinal mucosa. As much as $19 \%$ of total lipid of villus membrane was GSL (this is $\sim 4$ times the corresponding percentage for whole epithelial membrane), and the presence of fucolipids was limited to villus membrane (Forstner and Wherrett, 1973). Later, dog kidney MDCK cell line was used extensively for study of glycoprotein and GSL sorting in apical vs. basolateral membranes by Simons et al. and other groups. MDCK cells infected with envelope virus (e.g., influenza virus) bud through apical surface membrane, but not basolateral membrane. Lipid composition of envelope
B-1. 上皮細胞にみられる細胞部位の相違(極性)とスフィンゴ 脂質組成の相違

1つの細胞の表面膜の部位によって脂質組成が顕著に異なる ことが最初に発見されたのはラット小腸上皮細胞の刷子縁や緁 毛膜が分離精製され、それら膜組成とラット小腸上皮組織の脂 質組成の比較が可能になった1970年代のはじめである。Forstner and Wherrett (1973)は絨毛膜の糖スフィンゴ脂質含量が特に高 く、又当時発見されて間もなかったフコース含有糖脂質は絨毛 膜にだけ限局して見い出されることを示した。絨毛膜の糖ス フィンゴ脂質含量は総脂質の19\%で、全上皮組織糖スフィンゴ脂 質の4倍に及ぶ。絨毛膜は上皮細胞の頂端側膜を代表するので頂 端膜は側底膜より糖スフィンゴ脂質を多く含有する可能性が示 された。この可能性はSimonsらにより犬腎臟細胞MDCKにエン ベロープウイルス(インフルエンザウイルスなど)を感染させた系 を巧みに用いることにより追求された。エンベロープウイルス はMDCK細胞の側底側細胞膜から出芽しないが頂端側膜から出 
virus is therefore similar to that of apical membrane. Through this approach, the authors found that sphingolipids i.e., GSLs and SM are enriched in apical membrane (for review see Simons and van Meer, 1988).

\section{B-2. Electron Microscopic (EM) Demonstration of GSL Clusters in Phospholipid Bilayer}

Soon after scanning EM with freeze-etch technique of membrane became available in the late 1970s/ early 1980s, studies with distribution patterns of globoside and glycophorin, the major GSL and glycoprotein of erythrocytes respectively, indicated that globoside is clustered and present in domains separate from glycophorin domains (Tillack et al., 1983). Clustering of GSLs (Forssman antigen, GM1) was observed not only in plasma membrane but also at the surface of liposome consisting of GSL and synthetic phosphatidylcholine, where even cholesterol was completely excluded. Some clustered GSLs have regular lattice structure which appears crystal-like (Rock et al., 1991), but these images are regarded by some as EM artifacts. More recent studies with transmission EM or confocal fluorescence microscopy confirmed the clustering of GSLs at the cell surface (Sorice et al., 1997; Zhang et al., 2000).

\section{B-3. Detergent Resistance of GSLs, SM, and Cholesterol} together with Pericellular, Cytoskeletal, and Nuclear Membrane.

Based on the then-new concept of transmembrane organization of proteins (integral proteins) which can be solubilized only by detergent or chaotropic reagents (Marchesi et al., 1972), detergent extraction was applied in many subsequent studies for isolation and characterization of integral membrane proteins. The earliest study along this line was solubilization of glycophorin and other integral membrane proteins from erythrocyte "ghosts" by $1 \%$ Triton X-100. The insoluble residue contained cytoskeletal components together with GSLs and SM (Yu et al., 1973). In contrast to erythrocytes, the major detergentinsoluble residues of fibroblasts consist of (i) extracellular matrix (ECM), including fibronectin, Gp250 (today's tenascin or hexabrachion), and Gp140 (today's integrin); (ii) cytoskeletal system (particularly microfilaments, or actin fibers); (iii) all nuclear membranes and nucleus; and (iv) GM3 and other GSLs (Carter and Hakomori, 1981). Detergent-insoluble GSLs, particularly GM3, together with ECM components, increased upon cell confluency. GM3 was enriched at the site of cell attachment to glass surface; this attachment site was termed "detergent-insoluble substrate adhesion matrix" (DISAM) or "detergent-insoluble membrane" (DIM) (Okada et al., 1984). GM1 ganglioside as choleratoxin receptor in 3T3 cells was found to be detergent (Triton X-100)-insoluble, together with organized cytoskeletal system (Streuli et al., 1981). These early observations suggested that proper detergent can be used to separate clustered sphingolipids from membrane. In fact, many later stud-
芽するからである。つまり、ウイルス粒子の脂質組成は頂端側 細胞膜の組成と類似している。このアプローチを通して、彼ら はスフィンゴ脂質(主にGSLsとSM)が頂端側細胞膜に比較的多く 存在しているということを示した(Simons and van Meer,1988)。 B-2. 電子顕微鏡によるリン脂質二重層でのGSLクラスターの 証明

細胞膜のフリーズエッチング法を用いた走査電子顕微鏡 が、1970年代後半から80年代前半にかけて利用できるようにな り、赤血球の主なGSLと糖タンパク質であるグロボシドとグリ コホリンの分布パターンに関する研究が行われた。その結果、 グロボシドはクラスターを形成し、グリコホリンのドメインと は別に存在しているという事を示唆する結果が得られた(Tillack et al.,1983)。GSLs のクラスタリングは形質膜だけでなく、コレ ステロールを含まない、GSLとフォスファチジルコリンとだけ からなるリポゾームの表面でも観察される。GSLクラスターの 中には結晶構造のような規則正しい形を示すものもある(Rock et al ., 1991)。これら初期の走査電子顕微鏡による所見は一部の 人々により、電子顕微鏡像によくみられるアーティファクトで あるとみられ、永い間、一般の人々の興味をよばなかった。最 近の透過電子顕微鏡や共焦点蛍光顕微鏡を用いた研究は、細胞 表面でのGSLクラスタリングを裏付けた(Sorice et al., 1997; Zhang et al., 2000)。

B - 3. GSLS、SM、コレステロールは、細胞周囲マトリック ス、細胞骨格の膜、核膜と共に界面活性剂に不溶性である 生体膜につよく結合しているタンパク質は界面活性郕やカ オトロッピク試薬によってのみ可溶化することが出来、それら のタンパク質は膜を貫いているトランスメンブレンドメインを 持つという、当時としては新しい概念が確立された(Marchesi $e t$ $a l ., 1972)$ 。その概念を基礎として、多くの研究に界面活性剤抽出 が内在性膜タンパク質の分離や評価に応用された。その中でも 最も早かった研究は、1\% TritonX-100により赤血球ゴーストか らグリコホリンや他の内在性膜タンパク質を可溶化したもの だった。残った不溶性画分にはGSLsやSMと共に細胞骨格系の 成分が含まれていた(Yu et al.,1973)。赤血球とは対照的に繊維芽 細胞の界面活性剤に不溶な成分は(i)フィブロネクチンや Gp250 (今日のテネイシンもしくはへキサブラチオン)、Gp140(今日の インテグリン)などの細胞外マトリックス(ECM)；(ii)細胞骨格系 (特にミクロフィラメントやアクチン繊維)；( (iii)核膜と核；(iV) GM3や他のGSLsから成っていた(Carter and Hakomori, 1981)。 ECM成分と共に界面活性剂に不溶になるGM3などのGSLsは、細 胞密度が高ければ高い程増加する。GM3はガラス表面の細胞接 着部位に豊富に存在する; この細胞接着部位はdetergent-insoluble substrate adhesion matrix(DISAM)もしくは detergent-insoluble membrane(DIM) と呼ばれていた(Okada et al., 1984)。 3T3 細胞でコレラ毒素の受容体として機能しているGM1は一連の細 胞骨格系タンパクと共に界面活性剂(TritonX-100)に不溶である ことが見い出された(Streuli et al. 1981)。これら初期の観察は適 切な界面活性剤は細胞膜からのクラスターを形成したスフィン ゴ脂質を分離できるということを示唆している。事実、最近の 多くの研究では特定の膜分離の基礎として界面活性剂不溶性を 
ies used detergent-insolubility as a basis of separation, and the terms DIM or its synonym "detergent-resistant membrane" (DRM) (Brown and London, 1997) have been used. DIM/ DRM is highly enriched in GSLs and gangliosides, and so the term "glycosphingolipid-enriched microdomain" (GEM) was also applied (Hakomori et al., 1998; Rodgers and Rose, 1996).

\section{B-4. GSL clustering is required for GSL antigenicity and}

\section{GSL-dependent adhesion.}

Essentially all anti-GSL antibodies react much better with GSLs when presented in clustered state on cells or liposomes, than with non-clustered GSLs alone. Some anti-GSL antibodies recognize density of GSLs on solid phase, and show reactivity only when density is above a threshold value (Nores et al., 1987). GSL-dependent cell adhesion as typically observed with interaction of GM3-to-Gg3 or GM3 to other GSLs (Gb4, LacCer) also occurs above a defined threshold concentration of Gg3, Gb4, or LacCer (Kojima and Hakomori, 1991a). A model of cellular interaction of clustered GSLs with GSLs, synergistic with fibronectin-integrin adhesion, was shown (Kojima and Hakomori, 1991b). In all these cases, GSL clustering is essential for their recognition.

\section{B-5. Ganglioside Modulation of Growth Factor Receptor Function}

Starting with the observation that gangliosides modulate cell growth, a series of systematic studies showed that gangliosides may inhibit or activate signal transduction through growth factor receptor or hormone receptor function, particularly associated tyrosine kinase (see citations in Section 3.b). An idea that membrane-associated tyrosine kinase is affected by GSLs, particularly gangliosides, arose from these studies and has evolved into the concept of glycolipid signaling domain (see paragraph h), and growth factor receptor domain (see Section 3.b).

\section{B-6. Association of Glycosylphosphatidylinositol (GPI)- Anchored Proteins with Src Family Kinases}

The important biological notion for association of microdomain components with signal transducer molecules emerged in 1991. The first paper along this line was based on observations that many human GPI-anchored $\mathrm{T}$ cell markers (CD59, CD55, CD24, etc.) as well as mouse GPI-anchored Thy-1 and Ly- 6 , are associated with $\mathrm{p} 56^{\mathrm{lck}}$, suggesting that stimulation of GPI-anchored proteins in T cells may cause activation of tyrosine kinase, although biological effect on $\mathrm{T}$ cell activation was not shown (Stefanova et al., 1991). Many subsequent studies showed the presence of Src family kinases in DIM with or without GPI anchors. However, a functional connection of membrane receptors to transducer molecules was not demonstrated until 1997-98.
用いており、DIMとかdetergent-resistant membrane(DRM)(Brown and London, 1997)という言葉が使われている。DIM/DRMには G S L s やガングリオシドを多く含んでいることから、 glycosphingolipid-enriched microdomain(GEM)という呼び方も使わ れている(Rodgers and Rose, 1996; Hakomori et al., 1998)。

B - 4. GSL抗原性やGSL依存性細胞接着にはGSLクラスタリン グが必要

GSLの基本機能として古くから細胞抗原性が知られ、最近 は細胞接着機能が明らかになった。これらGSL機能はGSLが細 胞膜上でクラスターを形成していることに強く依存する。抗 GSL抗体は細胞膜やリポソーム膜上でクラスターを形成してい るGSLと強く反応する。抗GSL抗体の中には固相GSLの特定の 密度を認識し、或る闇值よりも高い密度の場合にのみ反応性を 示すものもある(Nores et al., 1987)。次にGSL依存性細胞接着の 場合を考えよう。GM3を高濃度に発現しているB16メラノーマ 細胞は、Gg3Cerやその他のGSL(Gb4, LacCer)をコートした固相 強く接着する。このような、典型的なGSL依存性の細胞接着に おいても接着をおこすGSL濃度に閾值があることが判明した (Kojima and Hakomori,1991a)。インテグリンを介する細胞接着と GSL依存性細胞接着は協調相乗性があるが、この場合にも GSL は不可欠である。

\section{B - 5. 増殖因子受容体の機能を調節するガングリオシド}

ガングリオシドが細胞增殖を調節するという観察を契機と して、ガングリオシドが増殖因子受容体やホルモン受容体の機 能を通して、シグナル伝達を抑制したり、活性化したりすると いうことが一連の体系的研究によって示された(Section 3.b参 照)。膜に結合したチロシンキナーゼが、GSLsの中でも特にガン グリオシドによって影響を受けるという考えは、これらの研究 から生まれ、糖脂質シグナルドメイン( $\mathrm{h}$ 参照)、増殖因子受容体 ドメインといった概念は徐々に発展してきた(Section 3.b参照)。 B-6. GPIアンカー型タンパク質とSrcファミリータンパク質と の会合

シグナル伝達分子がマイクロドメインに存在し、マイクロ ドメインの構成要素と会合しているという重要な概念は1991年 以来明らかになった。この線にそった最初の実験はマウスやヒ トのGPIアンカーに結合している種々のTリンパ球マーカーにつ いて行われた。即ちマウスのThy-1やLy-6、ヒトのCD59, CD55, CD24等がTリンパ球特有のシグナル伝達分子であるp56lck と会 合していることを示し、T細胞のGPIアンカー型タンパク質を刺 激すると、チロシンキナーゼの活性化を引き起こすかもしれな いということを示唆していた(Stefanova et al., 1991)。しかし、こ の研究では実際にT細胞が活性化されたかどうかは示されていな かった。その後の多くの研究ではGPIアンカーが有る、無しにか かわらずDIMにSrcファミリーキナーゼは存在するということを 示された。しかしながら、膜に存在する受容体とシグナル伝達 分子の機能的な関係は、1997年から1998年になるまではわから なかった。 
B-7. Biochemical Characterization of Caveolar Membrane, and Its Similarities to GSL/ SM/ Cholesterol/ GPI-Enriched Microdomain

Invaginations of plasma membrane, particularly well developed in endothelial cells and fibroblasts, discovered and termed "caveolae" over 45 years ago, have been recently characterized biochemically as being enriched in the scaffold protein caveolin, cholesterol, sphingolipids, and GPI anchor, and being detergent-resistant. Many signaling molecules and growth factor receptors are also claimed to be associated with caveolar domain, and involved in endocytosis and signal transduction (for review see Anderson, 1998).

However, many types of cells do not show caveolar structure. Nevertheless, low-density membrane fraction resistant to detergent (DIM fraction) is isolable from essentially all types of cells regardless of presence of caveolin or caveolar structure. Lipid/ protein composition of DIM is very similar to that of caveolar membrane fraction, although cholesterol content is much higher in membranes where caveolin is present than in fractions without caveolin (Iwabuchi et al., 1998a), and such membranes are structurally and functionally susceptible to cholesterol-binding reagents such as filipin and nystatin (Baorto $e t$ al., 1997; Schnitzer et al., 1994). Distinction between caveolar membrane and sphingolipid/ cholesterol/ GPI anchor-enriched membrane is generally difficult unless two approaches are applied: (i) immunoseparation by antibodies to various components, i.e., caveolin, GSLs, or other proteins (Iwabuchi et al., 1998a; Stan et al., 1997); (ii) determination of susceptibility to cholesterol-binding reagents.

Membranes previously termed DIM or DRM (see paragraph c above) are essentially the same as caveolar membrane. The term "raft," introduced by Kai Simons, has nowadays largely replaced the older terms, but the biochemical properties, as being mixtures of various membranes, are identical (see footnote on p.219).

\section{B-8. Functional Association of GSLs with Signal Transduc-} ers in GSL-Enriched Microdomain Separable from Caveolar

\section{Membrane}

Essentially all studies on caveolae, DIM, DRM, or GEM prior to 1997 paid no attention to function of GSLs, i.e., how GSLs are involved in cell adhesion, and how GSLs modulate or initiate signal transduction, as had been discussed for many years (Hakomori, 1990; Hakomori and Igarashi, 1995). A few studies since 1997 address the functional connection of GSLs in GSL microdomain to signal transducers. Some of them, conducted with a mouse melanoma B16 model, indicate that GSL-dependent adhesion through carbohydrate-carbohydrate interaction is coupled with transduction, initially to activate $\mathrm{cSrc}$, which in turn activates Rho A or FAK (Iwabuchi et al., 1998b; Yamamura et al., 1997). The functional unit termed GSD was clearly sepa-
B-7. カベオラメンブレンの生化学的性質とGSL/SM/cholesterol/GPIに富むマイクロドメインとの類似性

内皮細胞や繊維芽細胞で特にはっきりと観察される形質膜 の陥入は、 45 年以上も前に発見され、カべオラと名づけられ た。カベオラは最近になってその骨格タンパク質であるカべオ リンやコレステロール、スフィンゴ脂質、GPIアンカーに富み、 界面活性剤に不溶であるというような生化学的な特徵を持って いることが分かってきた。多くのシグナル分子や増殖因子受容 体はカベオラドメインに存在し、エンドサイトーシスやシグナ ル伝達に関係しているということも主張されている(総説： Anderson, 1998)。

しかしながら、細胞の中にはカべオラ構造を持たないもの 多数存在する。それにもかかわらず界面活性剂に不溶な低比重 膜画分(DIM fraction)がカベオリンやカベオラ構造を持たない細 胞においても分離することができる。DIMを構成する脂質/夕 ンパク質はカベオラメンブレン画分に非常に類似しているが、 コレステロール量はカベオリンのない画分よりもカベオリンを 含む膜のほうが多く(Iwabuchi et al., 1998a)、そのようなコレス テロール量の高い膜は構造的、機能的にフィリピンやナイス夕 チンなどのコレステロール結合試薬により影響を受けやすい (Schnitzer et al., 1994; Baorto et al., 1997)。カベオラメンブレンと スフィンゴ脂質/コレステロール/GPIアンカーを豊富に含む膜と の区別は次に示すような二つのアプローチが適用されない限 り、一般に困難である。：(i)構成成分であるカベオリンや GSLs、他のタンパク質などに対する抗体による免疫学的分離 (Stan et al., 1997; Iwabuchi et al., 1998a)；(ii)コレステロール結合 試薬に対する感受性の決定。

以前にDIMもしくはDRMと称した膜は、本質的にカべオラ メンブレンも含んでいる。今日これら以前に用いた呼び名は、 Kai Simonsによって提案されたラフトという呼び方に広く置きか えられているが、様々な膜の混合物であるという生化学的な特 性は同一である(P1の脚注参照)。

B-8. カベオラメンブレンから分離したGSLSに富むマイクロド メインにおけるシグナル伝達分子とGSLsの機能的結合

1997年より以前のカベオラやDIM、DRM、PGEMについて の研究は、本質的にGSLsの機能に注意を払っていなかった。つ まり、長年GSLsについて議論されていた問題：GSLsがどのよう に細胞接着に関わっているか、またどのようにシグナル伝達を 調節しているかということに関してである(Hakomori，1990; Hakomori and Igarashi，1995)。1997年になってGSLマイクロドメ インにおけるGSLsとシグナル伝達の機能的な関係に焦点を当て た研究が幾つかでてきた。それらの中にはマウスのB16メラノー マモデルを用い、糖鎖間相互作用を介したGSL依存的な接着 は、最初にcSrcが活性化され、その後RhoAもしくはFAKへとシ グナルが伝わることを示している。GSDと呼ばれる機能的工 ニットはカベオリン/コレステロールに富む、カベオラメンブレ ンから抗体を用いる分離法によりはっきりと分けることができ 
rated from caveolin/ cholesterol-enriched caveolar membrane by immunoseparation (Iwabuchi et al., 1998a). GD3 in rat brain is functionally associated with Src family kinase lyn, and stimulation of GD3 by its antibody induces tyrosine phosphorylation of lyn, although the physiological significance of this phenomenon remains unclear (Kasahara et al., 1997). Another series of studies showed that GM3 in DIM or GEM of human peripheral lymphocytes or T cell leukemia is associated with CD4 and p56 (Sorice et al., 1997), and that exogenous GM3 added to T cells induces phosphorylation of CD4, which in turn dissociates from p56 ${ }^{\mathrm{lck}}$ (Garofalo et al., 1998). Since the publication of the above papers, many studies have focused on functional role of GSLs in DIM or GEM. The term "glycolipid signaling domain" or "glycosignaling domain" (GSD) was proposed because adhesion/ signaling through GSL was shown to be coupled with signal transduction (Hakomori et al., 1998).
る(Iwabuchi et al., 1998a)。ラット脳のGD3はSrcファミリーキナー ゼであるlynと機能的に会合しており、GD3抗体によるGD3の刺 激はlynのチロシンリン酸化を誘導する(Kasahara et al, 1997)。し かしこの現象の生物学的意義はいまだ明確ではない。別の一連 の研究では、ヒト末梢リンパ球やTリンパ細胞白血病のDIMもし くはGEMのGM3はCD4やp531ck と会合し(Sorice et al.,1997)、ま た、外からGM3をT細胞に加えると、CD4のリン酸化を誘導し、 次にp53lckから解離することが示されている(Garofalo et al., 1998)。これらの論文が発表されてから、多くの研究がDIMもし くはGEMにおけるGSLsの機能的役割に焦点を当てている。接着/ シグナリングはシグナル伝達に連結していることが示されてい ることから、糖脂質シグナリングドメインもしくは糖シグナリ ングドメイン(GSD)という呼び方が提案された(Hakomori et al., 1998)。

\section{Sphingolipids have both hydrogen bond donors and acceptors}

\section{Glycerolipids have only hydrogen bond acceptors}
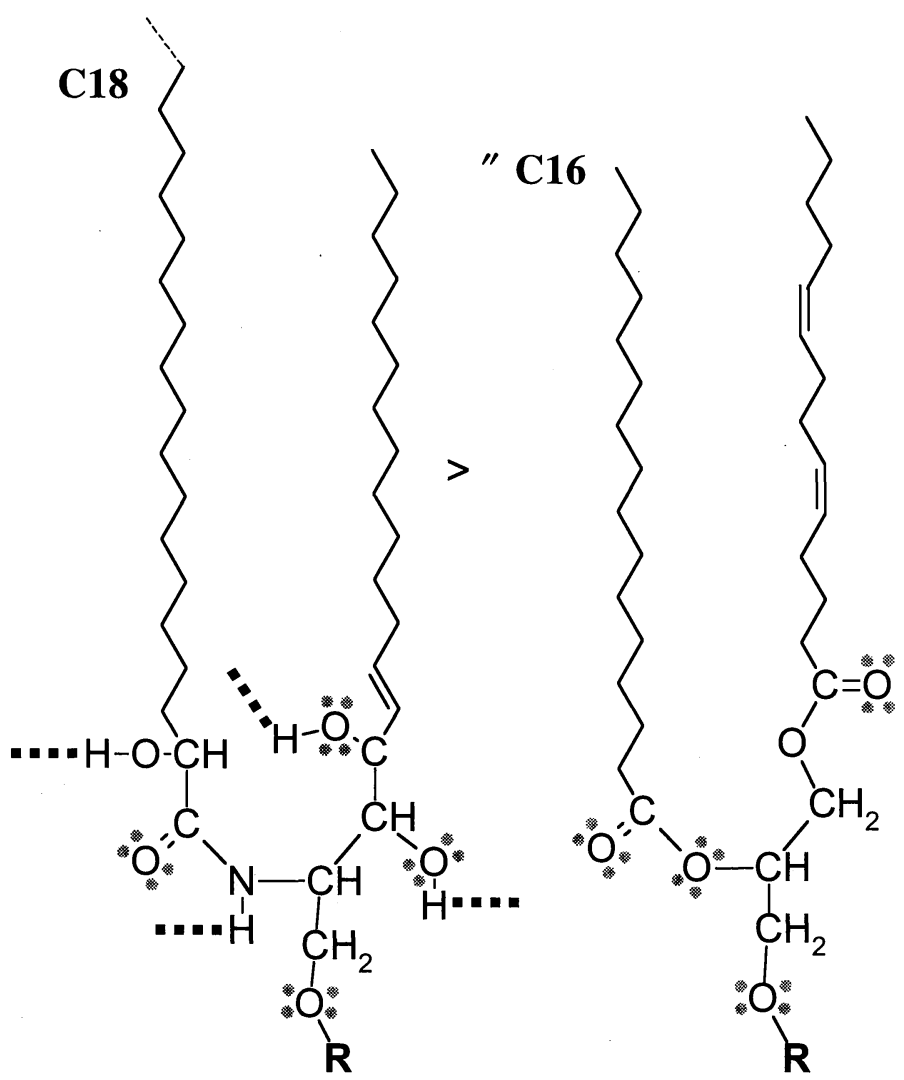

Fig. 4. Possible hydrogen bond acceptors and donors in sphingolipids, as compared to hydrogen bond acceptors in glycerolipids. Modified from (Pascher, 1976). 


\section{Current View of Multiple Microdomains}

Theoretically, we can distinguish several types of microdomain as below; each is characterized by common sphingolipid components SM and GSLs in combination with different amounts of cholesterol and different combinations of functional proteins. Sphingolipid clustering or lattice structure is based on the fact that $c i$ interaction between sphingolipids is stronger than that between glycerolipids. Sphingolipid acts as a hydrogen bond acceptor as well as hydrogen bond donor, whereas glycerolipid acts only as hydrogen bond acceptor (Fig. 4).

\section{C-1. GSL Signaling Domain or Glycosignaling Domain} (GSD)

These microdomains, as explained above, were isolated and characterized from B16 melanoma cells. Proteolipid proteins associated with GSLs have been detected, although their functional significance is still unclear. Surprisingly, GSD of B16 cells has very low cholesterol content and is resistant to filipin and nystatin, which bind to cholesterol and disrupt function of cholesterol-rich caveolar membrane. Whether similar microdomains are present, and separable from caveolar membrane, in other types of cells is unknown.

\section{C-2. Growth Factor Receptor Domain}

Modulation of signal transduction by gangliosides (for review see Hakomori and Igarashi, 1995; Yates and Rampersaud, 1998) was initially suggested by observations that GM3 inhibits FGF receptor function (Bremer and Hakomori, 1982) and EGF receptor tyrosine kinase (Bremer et al., 1986), and GM1 modulates PDGF receptor tyrosine kinase and function (Bremer et al., 1984) and strongly activates nerve growth factor receptor Trk A (Mutoh et al., 1995). Association of PDGF and EGF receptors with caveolar membrane, and their translocation from this membrane by activation of their tyrosine kinase, has been claimed (Liu et al., 1996; Mineo et al., 1996). However, there is no strong evidence to indicate that these growth factor receptors are associated with caveolin/ cholesterol-enriched caveolar membrane, or with GSD (see above). One possibility is that growth factor receptors are associated with an independent domain similar to GSD, but having different lipid environment and cytoplasmic transducer system, since the majority of growth factor receptors are found in high-density fraction.

\section{C-3. Domains Having Integrin/ TMP Complex or Other Associated Membrane Complex}

The major receptors involved in cell adhesion and motility are integrins having various combinations of $a$ and $b$ subunits. Integrins are closely associated in membrane with tetraspan membrane proteins (TMP) or other membrane proteins which facilitate and modulate integrin-mediated signaling to stimulate or inhibit cytoskeletal system, leading to adhesion or motility. Integrins are not found in caveolar membrane and DIM when prepared in $1 \%$ Triton X-100, but integrin level in
C. マイクロドメインの多様性についての現時点における見解 理論的に考えると、マイクロドメインのタイプを幾つか区 別することができる。；それぞれは、コレステロール量の違い や機能タンパク質の種類と通常のスフィンゴ脂質構成成分であ るSMやGSLsの組み合わせにより特徵づけられる。スフィンゴ 脂質のクラスタリングもしくは格子構造は、スフィンゴ脂質間 のcis相互作用がグリセロ脂質間のそれよりも強いという事実に 基づいている。スフィンゴ脂質は水素結合の受容体にも供与体 にもなりうるが、一方でグリセロ脂質は水素結合受容体として しか働くことができない(Fig.4)。

C-1. GSLシグナリングドメインもしくは糖シグナリングド メイン(GSD)

上で説明したこれらのマイクロドメインはB16メラノーマ細 胞から分離され、解析された。GSLsに結合するプロテオリピド タンパク質は検出されていたが、いまだにそれらの機能的重要 性は明らかになっていない。驚いたことに、B16細胞から分離さ れたのGSD膜のコレステロール含量はカベオラ膜に比べて非常 に少なく、カベオラの機能を壊すフィリピンやナイスタチンは GSD膜の機能を破壞しない。他のいろいろの細胞にも類似した マイクロドメインは存在するが、カベオラ膜から分離されるか どうか今のとろ不明である。

\section{C-2. 增殖因子受容体ドメイン}

ガングリオシドによるシグナル伝達の制御はFGF受容体の 機能やEGF受容体のチロシンキナーゼ活性がGM3により抑制さ れたり(Bremer and Hakomori, 1982; Bremer et al., 1986), GM1が PDGF受容体のチロシンキナーゼの機能を抑制したり (Bremer $e t$ al.,1984)、逆にGM1がNGF受容体(TrkA)のチロシンキナーゼを活 性化したりするという現象(Mutoh et al., 1995)により示唆された (総説 Hakomori and Igarashi 1995; Yates and Rampersaud 1998)。 一方、細胞がPDGFやEGFで刺激され、夫々の受容体のチロシン キナーゼが活性化されると、受容体は一時的にカベオラメンブ レンに移行する(Liu et al., 1996; Mineo et al., 1996)。しかしなが ら、これらの増殖因子受容体がカベオリン/コレステロールに富 んだカベオラメンブレン、もしくはGSDに結合しているという ことを示す強い証拠はない。一つの可能性は増殖因子受容体が GSDに類似した独立したドメインに存在しているということで あるが、主な増殖因子受容体は高比重画分に見られる以上、異 なる脂質環境と細胞質情報変換系の存在が考えられる。

C - 3. インテグリン/TMP複合体、もしくは他の膜結合型複合 体を持つドメイン

細胞接着や細胞運動に関係する主要な受容体は、 $\alpha 、 \beta+$ ブユニットの様々な組み合わせから成るインテグリンファミ リーである。インテグリンはテトラスパン膜タンパク(TMP)や その他膜タンパクと会合し、複合体をつくり、インテグリンか 細胞骨格系へのシグナルはインテグリン／TMP複合体を介し促 進されたり抑制されたりする。インテグリンは1\%TritonX-100を 用いて調整したDIMやカベオラメンブレンに存在しないが $0.5 \%$ 
DIM increases greatly when prepared in $£ 0.5 \%$ Triton $X$, or when $\mathrm{N}$-glycosylation of receptor and GM3 synthesis are restricted. Caveolin level in DIM decreases when N-glycosylation and GM3 level increase, whereby integrin is translocated from DIM to high-density fraction (Kazui et al., 2000). Integrin level in DIM increases greatly when cells are transfected with TMP CD82 cDNA, and lysate of such cells show exclusive co-localization of a5, a3, and CD82 in DIM but not in high-density fraction when cells are homogenized in 1\% neutral detergent Brij 98 (polyoxyethylene 20 oleylether). Coexistence of integrin and TMP is observed only under specific conditions, e.g., $\mathrm{N}$-glycosylation status of the receptor, and quality of detergent, i.e., Brij but not Triton X-100 (Ono et al., 2000). Therefore, the integrin/ TMP domain may be maintained in some special environment, but is obviously independent from other microdomains which are maintained in Triton X-containing media. Integrin avb3 and its associated protein CD47, together with heterotrimeric $\mathrm{G}$ proteins, are complexed with a cholesterol-rich microdomain (Green et al., 1999) which has lipid composition different from that of GSD.

\section{C-4. Cholesterol-rich, Caveolin-containing Caveolar Mem-}

\section{brane, Presumably with GPI Anchor}

Caveolar membrane is defined not by flask-shaped, invaginated morphology, but rather by the following characteristics: (i) very high cholesterol content and consequent susceptibility to cholesterol-binding reagents; (ii) presence of the scaffold protein caveolin family which may regulate signal transduction (Okamoto et al., 1998); (iii) selective association with certain types of GSLs, but exclusion of other GSLs, e.g., association of GlcCer and exclusion of GM3 in B16 caveolar membrane; (iv) selective association with certain types of signal transducers but not others, e.g., association of Ras $\mathrm{H}$ but not $\mathrm{cSrc}$ or Rho A in B16 caveolar membrane. Association of GPI anchors with caveolar membrane has been suggested by many studies (Anderson, 1998; Brown and London, 1997). However, association of GPI anchors with cholesterol-rich, caveolin-containing fraction or GSL-enriched GSD fraction has not been critically determined. There is a strong possibility that GPI anchors exist as an independent domain, presumably enriched in cholesterol.

Possible organization and functions of various microdomains (not including caveolar membrane) are summarized in Fig. 5.

\section{Acknowledgment}

I thank Dr. Stephen Anderson for scientific editing and preparation of the manuscript
以下のTritonXを用いた場合や、インテグリンのアスパラギン酸 結合糖鎖やGM3の合成が抑制された状態では、DIMのインテグ リン量がふえる。逆に、インテグリンのアスパラギン酸糖鎖や GM3合成がふえるとインテグリンは高密度画分へ移行し、DIM のインテグリンは減少する(Kazui et al., 2000)。TMP CD82 cDNA を細胞にトランスフェクションすると、DIMにおけるインテグ リンレベルは著しく上昇する。それは、中性の界面活性剤であ るBriji98(polyoxyethylene 20 oleylether)1\%でホモジナイズした 時、高比重画分ではなくDIMに $\alpha 5$ および $\alpha 3$ インテグリンが CD82と共局在することから示された。インテグリンとTMPの共 局在は、N - アスパラギン酸糖鎖の修飾を受けたレセプターや TritonX-100ではなくBrijiなどの界面活性剤を用いた系など、特 別な条件においてのみ見られる。つまり、インテグリン/TMPド メインは、いくつかの特別な環境によって維持されており、 TritonXを含む溶液で維持される他のマイクロドメインからは明 らかに独立した存在である。インテグリン $\alpha \mathrm{v} \beta 3$ とそれに結合 しているタンパク質であるCD47は、3量体Gタンパク質ととも に、GSDと異なる脂質組成のコレステロールに富むマイクロド メインと複合体を形成している(Green et al., 1999)。

C - 4. GPIアンカーはコレステロールとカベオリンに富むカベ オラメンブランに存在しているか ?

カベオラはフラスコ状の陥入した形態によって定義される のではなく、以下に述べる特徵によって定義される；(i)コレス テロールの含量が非常に多いこととコレステロール結合試薬に 感受性であること；(ii)シグナル伝達を制御するであろう骨格夕 ンパク質であるカベオリンファミリーの存在(Okamoto et al., 1998)；(iii)ある種のGSLsとの選択的な結合と他のGSLsの排除。 つまり、B16のカベオラメンブレンにおいてはGlcCerが結合して いるがGM3は排除される；(iv)ある種のシグナル伝達分子との選 択的な結合と他のものの排除。つまり、B16のカベオラメンブレ ンは、Ras Hと結合するがcSrcやRhoAとは結合しない。カべオラ メンブレンにGPIアンカーが結合していることは、多くの研究に よって支持されている。しかしながら、GPIアンカーの結合はコ レステロールに富み、カベオリンを含む画分なのか、GSLに富 むGSD画分なのかはっきりしていない。GPIアンカーは、おそら くコレステロールに富む、独立したドメインに存在している可 能性が高い。様々なマイクロドメイン(カベオラメンブレンを除 く)の考えられる構成と機能を図5に要約する。 


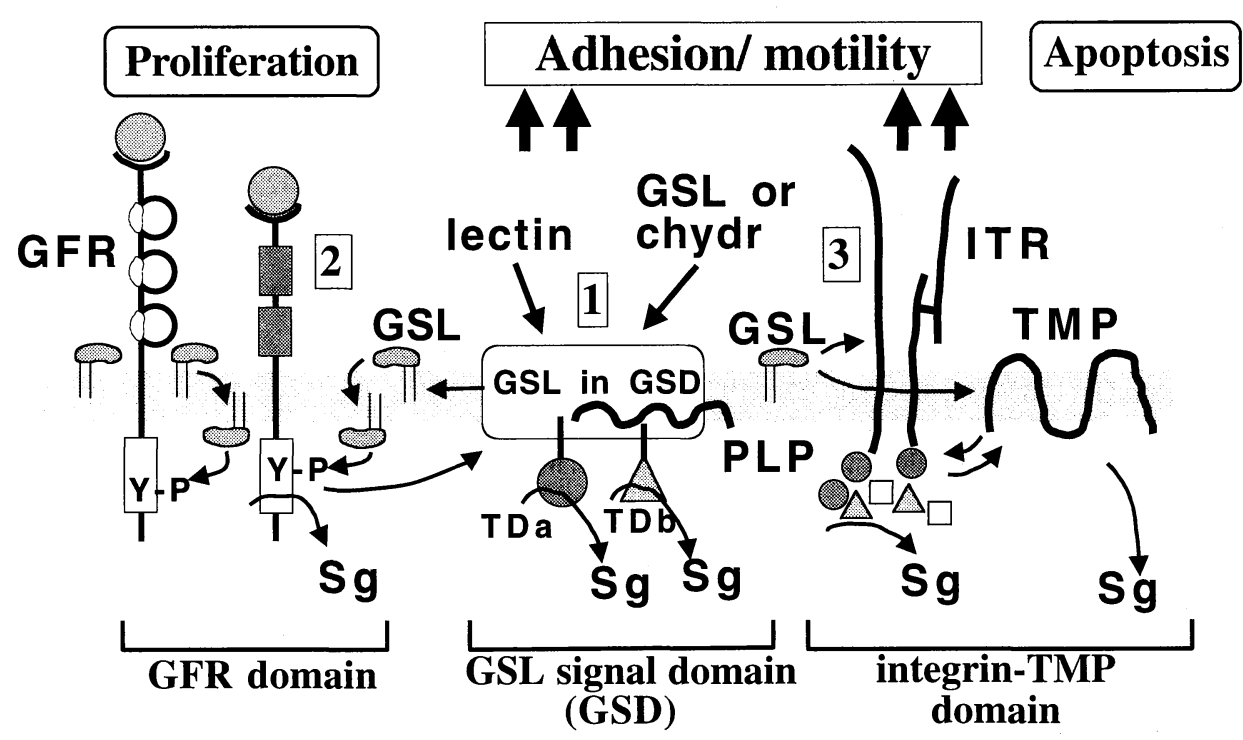

Fig. 5. Three types of microdomain, each mediating different functions with different receptors. (1) GSL-dependent adhesion coupled with signaling through clustered GSLs in GSD as major functional unit where various signal transducers (TDa, TDb) are associated; (2) cell proliferation mediated by growth factor receptors (GFR) clustered in a separate domain where they interact with GSLs, thereby inhibiting or promoting tyrosine kinase to change level of tyrosine phosphate (Y-P); (3) cell motility/ adhesion controlled by integrin receptor (ITR) complexed with tetraspan membrane protein (TMP) or other integrin-associated protein. GSL interacts with ITR or TMP, thereby altering tyrosine phosphorylation of transducers located at cytoplasmic site of ITR, or altering the facilitating effect of TMP. In process 1, lectins or complementary GSLs binding to GSL in GSD change signaling ( $\mathrm{Sg}$ ) through TDa or TDb, which may be modulated by proteolipid protein (PLP) associated with GSD. In process 2, GSLs inhibit or promote clustering of GFR, affecting signaling; alternatively, GSL may translocate ("flip") to directly interact with tyrosine kinase at cytoplasmic site, leading to altered signaling. GSL may promote or inhibit ITR function by an unknown mechanism, or modulate interaction of ITR with TMP, thereby facilitating ITR-dependent motility or TMP-induced apoptosis (Ono et al., 1999). There is clear evidence for integrin-TMP domain, although its lipid composition remains to be studied. Interaction of GFR with GSL has been well documented, but presence of a GFR-specific domain is still hypothetical. Caveolar membrane is not shown in this model.

\section{References}

Anderson, R. G. W. (1998). Annu.Rev.Biochem. 67, 199-225

Baorto, D. M., Gao, Z., Malaviya, R., Dustin, M. L., van der Merwe, A., Lublin, D. M., and Abraham, S. N. (1997). Nature 389, 636-639

Bremer, E. G., and Hakomori, S. (1982). Biochem.Biophys.Res.Commun. 106, 711-718

Bremer, E. G., Hakomori, S., Bowen-Pope, D. F., Raines, E. W., and Ross, R. (1984). J.Biol.Chem. 259, 6818-6825

Bremer, E. G., Schlessinger, J., and Hakomori, S. (1986). J.Biol.Chem. 261, 2434-2440

Brown, D. A., and London, E. (1997). Biochem.Biophys.Res.Commun. 240, 1-7

Carter, W. G., and Hakomori, S. (1981). J.Biol.Chem. 256, 6953-6960

Forstner, G. G., and Wherrett, J. R. (1973). Biochim.Biophys.Acta 306, 446-459

Garofalo, T., Sorice, M., Misasi, R., Cinque, B., Giammatteo, M., Pontieri, G. M., Cifone, M. G., and Pavan, A. (1998). J.Biol.Chem. 273, 3515335160

Green, J. M., Zhelesnyak, A., Chung, J., Lindberg, F. P., Sarfati, M., Frazier, W. A., and Brown, E. J. (1999) J.Cell Biol. 146, 673-682.

Hakomori, S. (1990) J.Biol.Chem. 265, 18713-18716

Hakomori, S., Handa, K., Iwabuchi, K., Yamamura, S., and Prinetti, A. (1998). Glycobiology 8, xi-xviii

Hakomori, S., and Igarashi, Y. (1995) J.Biochem.(Tokyo) 118, 1091-1103

Iwabuchi, K., Handa, K., and Hakomori, S. (1998a) J.Biol.Chem. 273, 33766-33773

Iwabuchi, K., Yamamura, S., Prinetti, A., Handa, K., and Hakomori, S. (1998b) J.Biol.Chem. 273, 9130-9138

Jain, M. K., and White, H. B. (1977) Adv.Lipid Res. 15, 1-60

Kasahara, K., Watanabe, Y., Yamamoto, T., and Sanai, Y. (1997) J.Biol.Chem. 272, 29947-29953

Kazui, A., Ono, M., Handa, K., and Hakomori, S. (2000) Biochem.Biophys.Res.Commun. 273, 159-163

Kojima, N., and Hakomori, S. (1991a) J.Biol.Chem. 266, 17552-17558

Kojima, N., and Hakomori, S. (1991b) Glycobiology 1, 623-630

Liu, P., Ying, Y., Ko, Y.-G., and Anderson, R. G. W. (1996) J.Biol.Chem. 271, 10299-10303 
Marchesi, V. T., Tillack, T., Segrest, J., and Scott, R. (1972) Proc.Natl.Acad.Sci.USA 69, 1445-1449

Mineo, C., James, G. L., Smart, E. J., and Anderson, R. G. W. (1996) J.Biol.Chem. 271, 11930-11935

Mutoh, T., Tokuda, A., Miyada, T., Hamaguchi, M., and Fujiki, N. (1995) Proc.Natl.Acad.Sci.USA 92, 5087-5091

Nores, G. A., Dohi, T., Taniguchi, M., and Hakomori, S. (1987) J.Immunol. 139, 3171-3176

Okada, Y., Mugnai, G., Bremer, E. G., and Hakomori, S. (1984) Exp.Cell Res. 155, 448-456

Okamoto, T., Schlegel, A., Scherer, P. E., and Lisanti, M. P. (1998) J.Biol.Chem. 273, 5419-5422

Ono, M., Handa, K., Withers, D. A., and Hakomori, S. (1999) Cancer Res. 59, 2335-2339

Pascher, I. (1976) Biochim.Biophys.Acta 455, 433-451

Rock, P., Allietta, M., Young, W. W. J., Thompson, T. E., and Tillack, T. W. (1991) Biochemistry 30, 19-25

Rodgers, W., and Rose, J. K. (1996) J.Cell Biol. 135, 1515-1523

Schnitzer, J. E., Oh, P., Pinney, E., and Allard, J. (1994) J.Cell Biol. 127, 1217-1232

Simons, K., and van Meer, G. (1988) Biochemistry 27, 6197-6202

Singer, S. J., and Nicolson, G. (1972) Science 185, 720-731

Sorice, M., Parolini, I., Sansolini, T., Garofalo, T., Dolo, V., Sargiacomo, M., Tai, T., Peschle, C., Torrisi, M. R., and Pavan, A. (1997) J.Lipid Res. 38, 969-980

Stan, R.-V., Roberts, W. G., Predescu, D., Ihida, K., Saucan, L., Ghitescu, L., and Palade, G. E. (1997) Mol.Biol. Cell 8, 595-605

Stefanova, I., Horejsi, V., Ansotegui, I. J., Knapp, W., and Stockinger, H. (1991) Science 254, 1016-1019

Streuli, C. H., Patel, B., and Critchley, D. R. (1981) Exp.Cell Res. 136, 247-254.

Tillack, T. W., Allietta, M., Moran, R. E., and Young, W.W.J. (1983) Biochim.Biophys.Acta 733, 15-24

Wallach, D. F. H. (1971). Cooperativity in biomembranes. In "The dynamic structure of cell membranes" (D. F. H. Wallach and H. Fischer, Eds.), pp. 181-199. Springer-Verlag, New York.

Yamamura, S., Handa, K., and Hakomori, S. (1997) Biochem.Biophys.Res.Commun. 236, 218-222

Yates, A. J., and Rampersaud, A. (1998) Sphingolipids as receptor modulators: An overview. In "Sphingolipids as signaling modulators in the nervous system" (R.W. Ledeen, S. Hakomori, A.J. Yates, J.S. Schneider, and R.K. Yu, Eds.), Vol. 845, pp. 57-71. New York Acad. Sci., New York, NY.

Yu, J., Fischman, D. A., and Steck, T.L. (1973) J.Supramolec.Struc. 3, 233-248

Zhang, Y., Iwabuchi, K., Nunomura, S., and Hakomori, S. (2000) Biochemistry 39, 2459-2468

Received on November 18,2000, accepeted on November 28, 2000

\section{Profile of the Author}

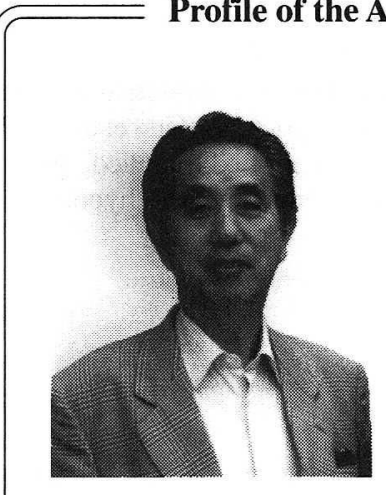

Sen-itiroh Hakomori

Sen-itiroh Hakomori was educated at Tohoku University School of Medicine, and earned the Dr. Med. Sci degree (Biochemistry) in 1956. Appointed to various faculty positions at Tohoku University School of Medicine, Tohoku College of Pharmaceutical Science, Harvard Medical School, and Brandeis University. From 1971 to present: Professor of Pathobiology and Microbiology, University of Washington, Seattle, WA. Simultaneous with these appointments, he has been Member and Program Head, Biochemical Oncology, Fred Hutchinson Cancer Research Center, Seattle, WA (1975-87); Scientific Director, The Biomembrane Institute, Seattle, WA (1987-96); and Head, Division of Biomembrane Research, Pacific Northwest Research Institute, Seattle, WA (1996-present).

His major study is structure and function of glycosphingolipids (GSLs), particularly involved in cell adhesion and signal transduction. Subsidiary observations such as discovery of cell surface fibronectin and its deletion during transformation, and cloning and defining of $\mathrm{ABO}$ gene structure, are also due to his studies. 